\title{
SOCIAL REPRESENTATIONS: Moçambican ethnicities
}

AS REPRESENTAÇÕES SOCIAS: Etnias Moçambicanas LAS REPRESENTACIONES SOCIALES: Etnias Moçambicanas

\section{Antonio Francisco Sefane \\ $\mathrm{PhD}$ in Social Psychology from John Kennedy University. Professor at UniSave University - Mozambique. assefas5@gmail.com. \\ 0000-0002-7711-4773}

\section{Joseneide dos Santos Gomes}

$\mathrm{PhD}$ in Social Psychology from John Kennedy University. Professor at the Municipality of São Paulo. santos.joseneide@ig.com.br.

0000-0002-8274-9685

Mailing Address: Save University. National Highway1. Parcel 76 Chongoene Xai-Xai Gaza, 1200. Mozambique.

Received: 10.12 .2020

Accepted: 11.20 .2020$.

Published: 01.01.2021.

\begin{abstract}
:
This article aims to bring a reflection on the theory of Social Representations from the perspective of Social Psychology. From the bibliographic review, an analogy is made between the theories of social
\end{abstract}

representations, to a concrete society, in this case, the Mozambican society. Social representations have been a topic widely discussed by several and categorized authors, many of them addressing the relationship between cognition-knowledge, individual and society. For this purpose, three Mozambican ethnicities were analyzed, namely, Macuas-Lomués, Ndaus and Tsongas, in which, based on the bibliographic verification of their cultures, beliefs and values, a real analogy can be drawn between the theories on social and cultural representations. the behaviors of these ethnic groups, which make clear the different social representations in the different regions that form the country called Mozambique.The basis of the research was the bibliographic review, both to address the theoretical supports, as well as to address the Mozambican reality.

KEYWORDS Representations; Ethnicities; Macuas; Tsongas.

\section{Introduction}

In the classic definition according to Jodelet (1985), social representations are modalities of practical knowledge oriented towards communication and the understanding of the social, material and ideational context in which we live.

In turn, Fuller (1988) highlights the contribution that Social Psychology comes to make by demystifying the dichotomy between individual and society, and between psychologism and sociologism. "Psychologism, involves the assessment of the mental state that the producer brings to the knowledge process, while sociologism, involves the evaluation of the consequences of the knowledge process - the knowledge products without taking into account the mental state of the producer".

Fuller (1988) continues to state that Social Psychology seeks to overcome this dichotomy by viewing the individual and his mental productions as products of his socialization in a given social segment. Individuality, in this perspective, emerges as a structured structure that has structuring potential.

It is in this context that the ongoing research will be based on this approach of Social Psychology to make an analogy between what the authors say about social 
representations and try to translate the philosophical / theoretical approaches to a Mozambican reality.

\section{Theoretical approach to the theme}

In Vigoysky's perspective (1978) Individual, he is always a social entity and, as such, a living symbol of the group he represents.

Thus, the individual in the group, typical of quantitative approaches, can be approached as a generic subject - as the group in the individual - as long as we have an adequate understanding of the social context it inhabits: its habitus and the broader web of meanings in which the representation object is located (Vigoysky, 1978).

As systems of interpretation, social representations regulate our relationship with others and guide our behavior. Representations also intervene in processes as varied as the diffusion and assimilation of knowledge, the construction of personal and social identities, intra and intergroup behavior, actions of resistance and social change. As cognitive phenomena, social representations are considered as the product of an activity of appropriation of external reality and, simultaneously, as a process of psychological and social elaboration of reality (Jodelet, 1989, p.36-37)

For Spink (1993), this approach above may possibly be the most valuable contribution of Social Psychology to the study of social representations: the emphasis on the process of elaborating representations based on the social practices that define and are defined by them.

The theory of social representations presents a problem that is, historically, of interest to other human sciences, such as history, anthropology and sociology (Jodelet, 2001).

For Vala (1996) it is a scientific theory about the processes by which individuals in social interaction build explanations about social objects.

Continuing, Vala (1996) speaking of the human activity that plays this important role in social representations, quotes some authors in the following terms:

"In the work Principles of Psychology", W. James (1890) states that two major orientations dominate the thinking about human activity: the theory of faculties and the theory of association. The first emphasizes the idea of man as an entity that has the capacity to know, desire and feel.

It is in this perspective that Bandura (1986) refers to basic human faculties, such as, for example, the ability to create symbols, the capacity for self-regulation and selfreflexivity. In the second orientation, the agent and his faculties cease to be explanatory principles and become the object of explanation. As James says, "the common elements 
of the different mental facts are sought, rather than the common agent that underlies them" (p. 1). The metaphors that represent these two orientations are, in James's language, respectively, the "autonomous man" and the "plastic man". The autonomous man is the subject of the action, and the action stems from his faculties. The plastic man is "acted", he is a passive subject."

Moscovic (1984) says that the psychologist and, often, the sociologist, address the facts. They usually use a binary read key. This key corresponds to the separation between subject and object, which are given and defined independently of each other. The psychologist places the "ego" (the individual, the organism) and, on the other, the "object", or, on the one hand, a repertoire of responses and, on the other, the stimulus: Therefore, when we study visual perception, we consider the visual apparatus and the color or intensity of a point of light, due to the way the eye reacts to light stimulation. Likewise, when studying intellectual processes, we are interested in the way the brain treats information from the outside world. And we want to know how you learn, organize and transform it into defined behavior. The relationship scheme remains like this:

Individual subject (ego, organism) Vs Object (environment, stimulus).

In sociology the individual is seen as a collectivity (the group, the social class, the State). Or we can take into account a multitude of subjects who change, negotiate, share the same worldview. As for the object, it also has a social value, representing an interest or an institution. In addition, the object is sometimes made up of other people, by other groups, who form what we call the human environment. Obviously in all of these cases, we are faced with a differentiated subject and object according to economic or political, ethical or historical criteria. Regardless of the type of differentiation, what we want to know is how the various categories of individuals behave in society, how they reproduce the existing hierarchy, how they distribute wealth or exercise their powers. Or how the action of each individual, provided with its own interests and objectives, is transformed into collective action (Moscovic, 1984).

For Moscovici (1978) Social Representations are almost tangible entities. They circulate, intersect and crystallize incessantly, through a speech, a gesture, a meeting in our everyday universe, thus constituting a modality of particular knowledge that has the function of elaborating behaviors and communicating between individuals.

Information is the organization of the knowledge that the group has about a given social object. That is, depending on the level of knowledge of the group, the information about the object will be more accurate, and its representation may differ from a group with little, no information, or with different information (Moscovic, 1978). 
Continuing to work on the field of representations, Moscovici (1978) considers it the image that the social group builds of the object, the social model referring to aspects of the object's representation.

\section{Some Mozambican ethnicities and their characteristics}

Mozambique is a country of great cultural diversity, and like most countries in Africa, it does not have a specific identity, presenting aspects that link it to other neighboring countries and even to other continents. Upon gaining independence in 1975, after almost fifteen years of war against the Portuguese, Mozambican leaders sought to eliminate the language of the colonizer, but this became impractical in view of the variety of languages present in the country, which have regional importance, but do not reach national. (Santiago, 2012).

Continuing, Santiago (2012) mentions that in all Mozambique there are 43 languages, of which Macua, Tsonga (Shangaan), Sena, Lomwe, Chuwabu and Nianja stand out. Tsonga, for example, is spoken by the ethnic group of the same name, which is spread across Mozambique, South Africa, Zimbabwe and Swaziland. The Nianja language, on the other hand, is spoken by the Chewa ethnic group and some other peoples close to them, in Zambia, Zimbabwe, Mozambique and Malawi, and in the latter country it is official.

For Marcer (1961), tribe and ethnicity are two almost equivalent terms. An ethnic group is a "closed group, descending from the same ancestor or, more generally, having the same origin, having a homogeneous culture and speaking a common language.

In turn, Honigmann (1964) states that "in general, anthropologists agree on the criteria by which a tribe (as a system of social organization) can be described as a common territory, a tradition of common descent, a language common, a common culture and a common name.

For this research, we will characterize three ethnic groups more representative of each region of Mozambique, that is, one in the north, another in the center and also in the south, comparing their cultural identities.

For Damatta (1986, p. 123), quoted by Meque (2018) the term culture derives from the Latin culture, which means the act of planting and developing plants, agricultural activities. It is also associated with the Latin verb colere (caring for plants) to cultivate. The word was originally related to the cultivation of the land. The same author believes that probably, the soulful relationship with nature as a parameter for understanding the world, made the term agricultural start to translate, also, the patterns of behavior on the norms, rules and social and relationship content of men. 


\section{The Macuas Lomués}

According to Medeiros (1997), The Macua people are descendants of a large Banto people originating in the Central African region (large lakes), that is, the large Congolese forests, which migrated to the southern African region in search of fertile land. These Emakhuwa and Elomwe speaking people were represented in Niassa by the MacuasLomwes, Macuas-Chirimas, and Macuas-Meto. These ammetho occupied from the Lurio river the source of the messalo. The macuas-lomues (alomwes), occupied the other part of the Lurio river and these peoples were represented by lineages of exogamic clans: alakassi, amirassi, anela, amale, amirolo, aseleja and achepani.

Currently these people live in the north of Mozambique, with about 300,000 km2, covering part of the provinces of Cabo Delgado, Niassa, Nampula, Zambézia, it is bounded to the north by the river (Licungo nearby) Rovuma a, east the Indian Ocean, south river Licungo, near the Zambezi River and the west Lugenda River. Due to the migrations of the 19th century and the slave trade in the 18th-19th centuries, macuas can also be found in Malawi, Tanzania, Madagascar, Seychelles and Mauritius (Medeiros, 1997).

\section{Culture as a form of social identity}

Macuas have specific cultural characteristics, with capulana being one of the garments that identifies them.

Cabo Delgado is a province in Mozambique that has great cultural influence from neighboring countries, including Tanzania and Malawi. Besides enchanting those who visit the province, it is from this multicultural context that, for example, the women of the Makuwa people are well dressed in capulanas. In addition to capulanas, they make very artistic face paintings with the local cream called musiro. These women called 'Makuwas' or the Makuwa people, dressed in colors of great joy, to the tone of the drum and with the pleasant sound of elulu (click of the tongue) sometimes spend all day singing and dancing (Fonseca and Tristoni, 2013).

Figure 1 Image of Macua women with capulana as a symbol of their characteristic garments and with musiro on their faces. 


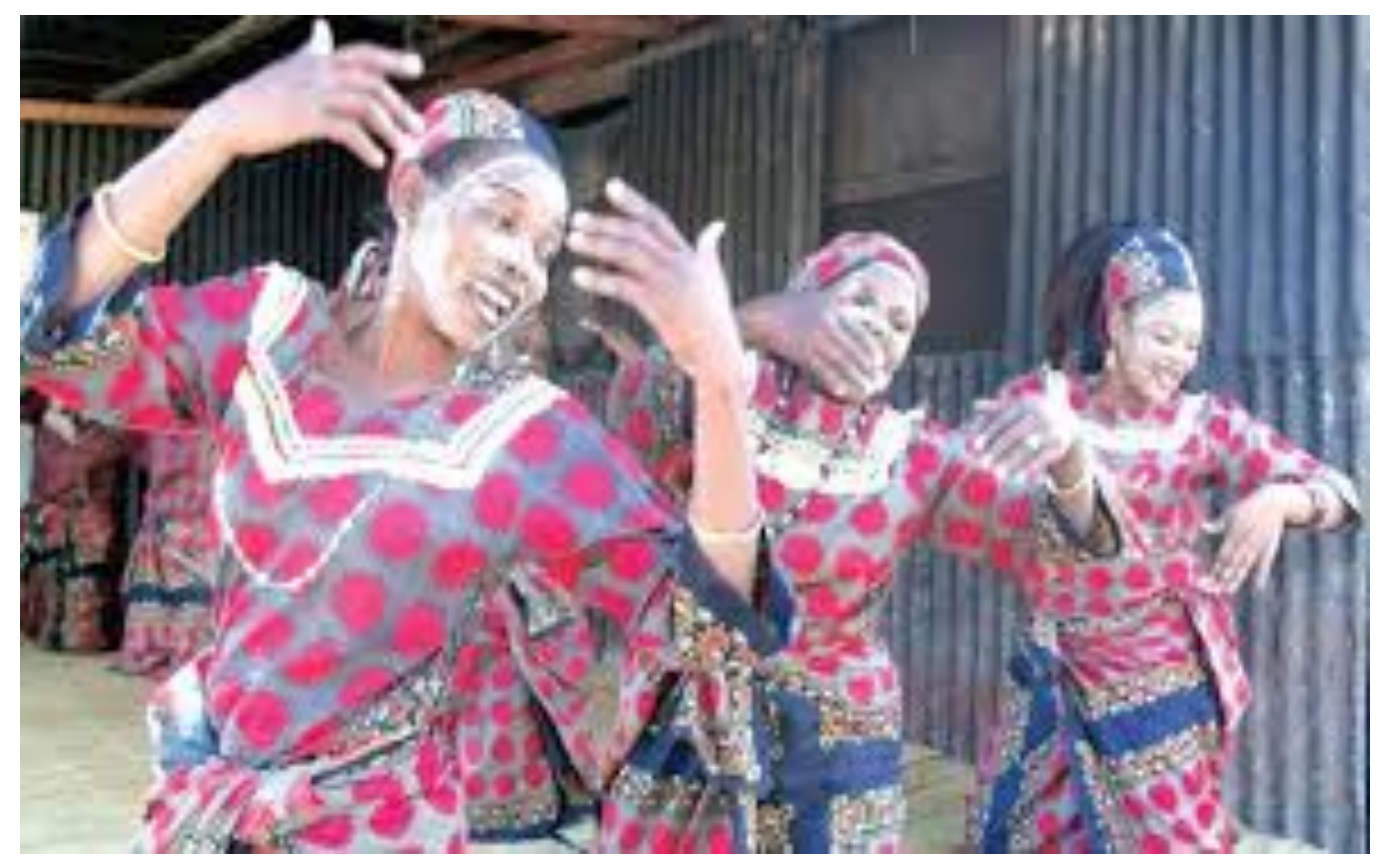

Source: Picture by google.com/search

In traditional societies in Mozambique, each human phenomenon represents an important fact for the population, it is in this context that birth in the macuas is accompanied in specific rites.

According to Martrinez (1989) the birth of a child is one of the most important events in Macua society. The child is wanted and expected by parents, guardians and family members, by the inhabitants and finally by all members of society, because everyone loves life and wants it to continue.

Each time a child is born, this ideal is concretely realized. Another child means, for the family and society, concrete hope that life does not end, it is a sign that ancestors continue to be intermediaries between the source of life and society. That is why the birth of a child is a cause for celebration for the whole community, a day of joy for everyone (Martinez, 1989).

The Makuwa people have no written record in their mother tongue and their stories and customs are revealed through oral language, through rituals that are present in the life of the Makuwa people, from birth to death. All of these rituals are expressed in the native language of the Makuwa people and, although the country's official language is Portuguese, the Emakhuwa language ends up being the official language of the people. An example of this are the so-called rites of initiation into adulthood for girls, and circumcision (cutting the boy's foreskin), during this ritual, the elders transmit advice to boys and introduce them into adult life. It should be noted that the use of the Emakhuwa language becomes evident during the times when the Makuwa people get together to experience their customs (Fonseca and Tristoni, 2013). 
Fonseca and Tristoni (2013), continue to state that: Regarding gastronomy, although there is an importation of cuisines from other peoples, such as, for example, Indians, Arabs and Portuguese, Makuwa cuisine is quite rich and traditional. There are several types of food, such as "shima" (food made from maize flour and sorghum, nikujukhu (food made from piled corn and yugo beans), matapa (a mixture made from cassava leaves), mwatranka (a kind of polenta made from manioc flour.) These foods reveal the identity of the Makuwa people.

\section{The Ndaus}

The origins of the Ndau people are not easy to trace due to the scarcity of sources and the existing contradictions. However, it seems safe to say that the group's origins are linked to the fragmentation of the Muenemutapa and Dom Pire kingdoms to the expansionist cycles of Shonas-Caraga lineage groups, the Rozvi, from the central plateaus of Zimbabwe towards the Indian coast (Malua et al, 2014).

Malua et al (2014) continues to state that the Ndau are an ethnic group that inhabit the Zambezi valley, from central Mozambique to its coast, and east of Zimbabwe south of Mutare. The ancestors of the Ndaus were warriors from Swaziland who joined with the local population, constituted ethnically by Manikas, Tewes, Barwes in the provinces of Manica and Sofala. The Ndaus speak a language that belongs to the Xona language family.

According to several authors, the term Ndau was applied to these populations by Nguni invaders from the south, who occupied this region during the second half of the century. XIX. The term would relate to the traditional way in which these populations salute a chief, or an important foreigner, which is to kneel down, clap their hands and repeatedly and rhythmically shout "ndau ui ui, ndau uiui" (Florêncio, 2002), cited by Marta Patricio (2011).

Given this historical link between the Rhodesian Ndaus, now Zimbabwe, their relationship continues, even with the establishment of a border, according to witness Ptaricio (2011) when he quotes Florêncio, (2005), stating that: "In effect, the establishment of the the drawing of Mozambican borders was not enough to imply the rupture of a set of relations of political subordination, with an enormous magicalreligious component, between the Mozambican and Rhodesian chieftains. Despite the efforts of the Portuguese colonial authorities, these relations have been perpetuated and, even today, Mozambican VaNdau chiefs feel dependent on, or subordinate to, Zimbabwean chiefs, at least from a magical-religious point of view". 


\section{Revisto Observatório}

Second, Meque (2018) The Ndau are strongly influenced by the belief in the power of ancestors that is manifested through the spirits that are incorporated into the living, to say what the living should or should not do about certain family or community issues. From the point of view of social coexistence, these beliefs guide the community towards good social conduct, thus creating a harmony in family coexistence from the fear that the dead can do for the living. Crimes are accompanied by dances with rhythmic beats or with the palms of the hand.

Continuing, Meque (2009) states that: In general, the Ndau people practice four (4) main dances: Ndhokodo, Mandowa, Makwaia, Madjzhoka (the latter is ceremonial and spiritual and is exclusively linked to healing). However, as mentioned, in Sofala, the Ndau are mainly in Machanga, Chibabava, Búzi and Cidade da Beira. Therefore, in each district there are other local dances such as Mukapa in Búzi and Xiquema in Machanga. However, some dances tend to disappear due to the influence of globalization.

Figure 2 Image of traditional dances with healers, one of the cultural identities of the Ndau people.

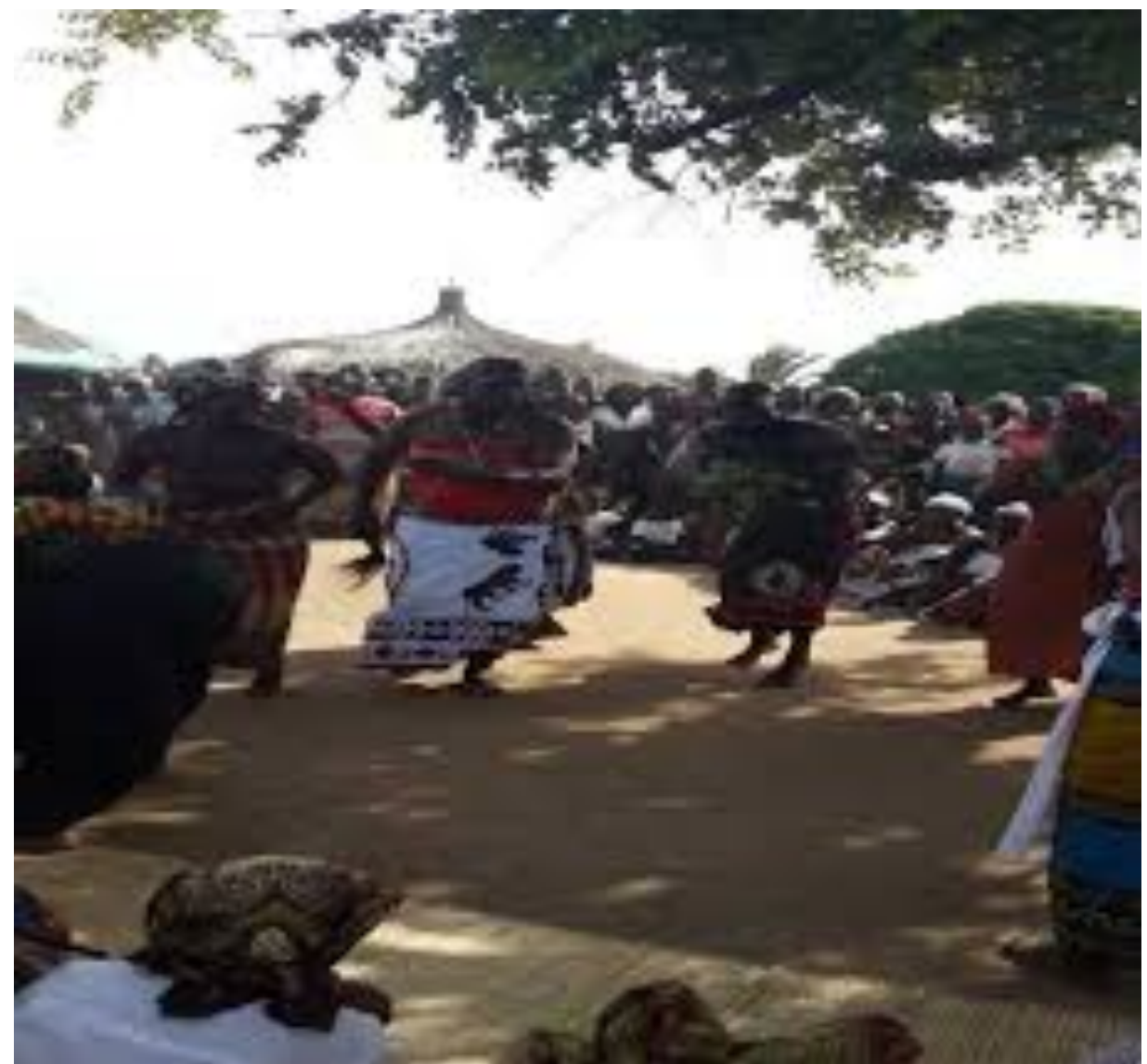

Source:https://www.google.com/search?sxsrf=ALeKk01s1jgp22YMU6wus18OgbBkJjkUQ:158816 4729874. 


\section{The Tsongas}

Finally, one of the most representative groups in the southern region of Mozambique will be characterized, the Tsongas. Let's see how Timbane (2014) citing Guthrie (1948) and Ngunga and Faquir (2011), characterizes tsongas:

"Tswa-ronga or tsonga, according to Guthrie (1948), consists of three languages: Xirhonga, Citshwa and Xichangana. These languages are intelligible and occur in the southern region of Mozambique, covering the provinces of Maputo, Gaza and Inhambane.

According to Ngunga and Faquir (2011) the languages of the Tsonga group have variants: (a) xichangana: xihlanganu, xidzonga, xin'walungu, xibila and xihlengwe; (b) ronga: xilwandle, xinondrwana, xizingili and xihlanganu; (c) citshwa: citshwa, xikhambani, xirhonga, xihlengwe, ximhandla, xidzhonge and xidzivi. This subdivision is the result of intense debates at seminars between Mozambican linguists and elsewhere, in an attempt to describe and organize the designation of these Mozambican Bantu languages."

In turn Junod (1996) quoted by Coelho (2009), characterizes the Tsonga people as follows: "The Tsonga tribe is made up of a group of Bantu populations established on the east coast of South Africa, from the vicinity of Santa Bay Lúcia, on the coast of Natal, to the Save River, in the north. [...]

The Tsongas confront to the south with the Zulus and the Swazis; to the west with Mabis, Lautis and other Suthu-pedis clans; to the north with Sales and Nyais in Zoutpansberg and Rhodesia and Ndraws near Save; and to the east with the Tongas, near Inhambane, and the Copis to the north of the mouth of Limpopo (Jnod, 1996: 33-4).

Jundo (1996) talking about one of the aspects that culturally characterizes tsongas related to guessing, says that:

"One of the most interesting aspects in these representations about nature is limited to one of the most central activities of Tsonga life: the divination or oracle of the bones. Styled by Junod astragalomancy, in Tsonga it was known as Nholo or Bula. Originally from kabula which means "to speak"; it had the meaning of "The Word" or "The Revelation". This religious practice aimed to diagnose the causes of the problems that emerged within the communities. They could be of a different order such as disease, cultivation, drought, business, politics, etc. The oracle tries to predict, explain and control almost all aspects of Tsonga villages and clans (Junod, 1996: 463-4 - tome II)."

Another of the cultural identities of the Tsonga people, is the lobolo: "Lobolo is a custom cultivated today in southern Mozambique. The bride's family receives money for the loss that represents the marriage and the daughter's move to another home. 
However, the lobolo has the meaning of uniting the ancestors of the two families (that of the groom and that of the bride), asking the ancestors to give luck to the new home and above all the bride's fertility; guaranteeing the protection of women in her husband's family and finally her husband's family; guarantee the right for the bride to remain at the husband's house to take care of the children, in case he dies (Langa, 2012)."

According to the characterization of the Tsonga people, made by Ngunga and Faquir (2011), this social group is subdivided into so many other small or large ethnic groups that inhabit the southern region of Mozambique. One of the aspects that reflects this characterization, are the traditional dances.

According to the colgiomoz website, in the southern region of Mozambique we find the following traditional dances: Timbila and zoré in the province of Inhambane, xigubo and makhwai in the provinces of Gaza and Maputo, Ngalanga in the province of Maputo, xingomana in the province of Gaza etc.

Figure 3 Image of one of the traditional dances in southern Mozambique.

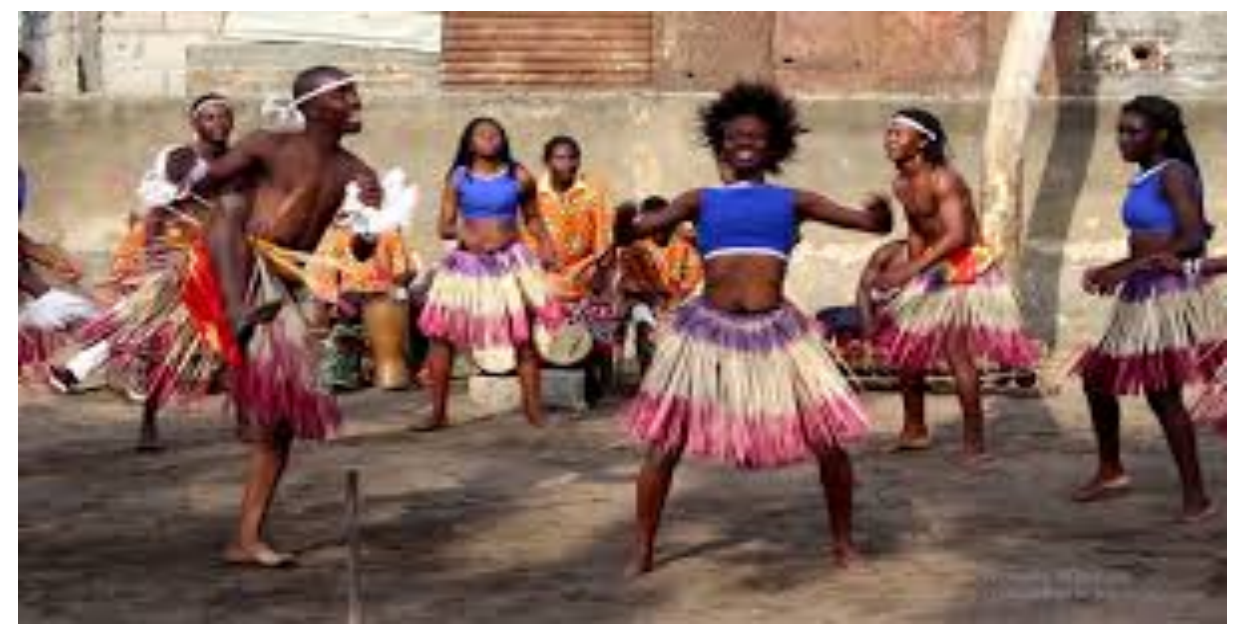

Source: www.colgiomoz.blogspot.com

\section{Final considerations}

As stated above, the objective of this work was to make an anarchy between the theories of social representations and some ethnic groups that make up the Mozambican cultural mosaic. The choice of Macuas ethnicities, Indians and Tsongas, was a conception of the author and was not based on any scientifically established criteria, however, it is believed that these ethnicities may be representative of the different Mozambican social / cultural extracts. 
In the theoretical approach made throughout the work, it was possible to make a connection between the theories of social representations and the specific characteristics of each entity, if we do not see:

Jodelet (1985) says that social representations are modalities of practical knowledge oriented towards communication and understanding the social, material and ideational context in which we live.

For Moscovici (1978) Social Representations are almost tangible entities. They circulate, intersect and crystallize incessantly, through a speech, a gesture, an encounter in our daily universe, thus constituting a modality of particular knowledge that has the function of elaborating behaviors and communication between individuals.

These approaches by these two authors are supported by the characterization made to the three ethnic groups analyzed above, because it was possible to notice how each ethnic group interprets its context from the historical to the cultural context, to the interpretation of its environment or context and, from there, to shape Behaviors, idealizations of your world and design your ways of communication and living together.

In turn, Valá (1996), when talking about social representations, says that through interaction, men find ways of explaining objects of a social nature. We find in these three ethnic groups the way in which they build their way of life, their habits from their interaction. This construction, as we have seen, is passed on from generation to generation.

One of the aspects that was notorious in the characterization of Mozambican ethnicities, was the culture that is one of the main identities of a determined social group, so that some specific characteristics of some cultural manifestations of each ethnic group were brought up to images.

James (1890) speaks of the autonomous man, as one who is the subject of action and the plastic man who is acted or is a passive subject. By making an analogy of this approach to James, the human action of interaction can be characterized, the autonomous man, as one who reflects in what he sees, tries to understand and can add value in what was previously established by the ancestors of his group in what the interpretation of the object concerns. And, the plastic man when passively complies with the rules of his society pre-established and that are transmitted from generation to generation.

In the three ethnic groups analyzed here, this phenomenon of plastic man was more dominant, since each ethnic group maintains the interpretation of phenomena and social objects to the principles established by their ancestors, such as initiation rites, dances, beliefs to spirits and the use of bones to interpret events within the group. 
Another important phenomenon that was evident throughout this bibliographic research was the fact that the Macuas, as well as the Ndaus and Tsongas, their social representation, is not limited to national borders, having links with neighboring countries, in the case of the Macuas. with Tanzania and other great lake countries, for the Ndaus, their umbilical cord has connections with Zimbabwe and the tsongas with South Africa and Swaziland. Here we find in fact the genesis of social representations that characterize united people by the same interpretation of the social object and the construction of knowledge from the cognition-object relationship, which will shape the beliefs, culture and common values that will dictate their conduct and behavior.

Regarding this intercountry or regional link between ethnic groups, it is important to repeat what Patrício (2011) says about it: Mozambique is an invention of Portuguese colonialism in the sense that it corresponds to a political-territorial unit that did not exist before the occupation process outlined at the Berlin Conference. Its constitution did not count on the participation of African societies, and for this reason the idea of a "Mozambicanity" has been largely seen, in certain areas, as an exogenous imposition, not obeying the logic or conceptions of these populations.

Finally, it is concluded that the three ethnicities chosen, can give an idea of the "marriage" between the theories about social representations analyzed in a context of Mozambican ethnicities.

\section{References}

Bandura A, A. (1986), Social Foundations of Thought and Action, Englewood Cliffs, 914 Printece Hall.

Coelho, M. (2009), O Mundo natural dos tsongas no discurso de Henri Junod.em https://anpuh.org.br/uploads/anaissimposios/pdf/201901/1548772005_6012ea4 7f989cf3836fa024222b5618c.pdf, assessado aos 01/05/2020.

Damatta, R. (1986). Exploração: um ensaio de sociologia interpretativa. Rio de Janeiro: Rocco.

Florêncio, F. (2002) Identidade Étnica e Práticas Políticas entre os vaNdau de Moçambique. Cadernos de Estudos Africanos, no 3, p. 39-63, Jul./Dez.

FlorêncioL, F.(2005) Ao Encontro dos Mambos - autoridades tradicionais vaNdau

e Estado em Moçambique. Lisboa: ICS, 298 p.

Fonseca L., Tristoni L.H. (2013), Os desafios que o povo makhua encontra para manter sua cultura diante do plurilinguismo na região de cabo delgado, Moçambique, revista Travessia, Maputo.

Fuller, S., 1988. Social Epistemology. Bloomington and Indianapolis: Indiana University Press. 
Guthrie, M. (1948) The classification of the bantu languages. Tese. (Doutorado em Linguística). University of London. London: IALU/ IOUP.

Honigmann, J. (1964) "Tribe", A dictionary of the social sciences, Glencoe, Free press.

James, W. (1890), The Principies of Psychology, Nova lorque, Holt.

Jodelet, D. (1989). Les Représentations sociales: un domaine en expantion. Em D.

Jodelet (org.), Les représentations Sociales. Paris: Press Universitary de France. Jodelet, D.1985), La representación social: Fenómenos, concepto y teoría. In: Psicologia Social (S. Moscovici, org.), pp. 469-494, Barcelona: Paídos.

JodeletT, D. (2001). Representações sociais: um domínio em expansão.In D. Jodelet (Ed.), As representações sociais (pp. 17-44). Rio de Janeiro: UERJ.

Junod, A. (1996), Usos e costumes dos Bantu. Tomo I. Maputo, Arquivo Histórico de Moçambique.

LangaA, L.(2012), Cultura do povo Moçambicano, zona sul em http://liandralanga.blogspot.com/2012/01/cultura-do-povomocambicano-zona-sul.html,assessado aos 01/05/2020.

Malua, R. Maugente, J. Notice, T. Eeneio, S. Manuel, L. Muadissinar, D. (2014).

Etnologia dos Povos Africanos-Ndau. (em https://malua7rcbm.blogs.sapo.mz/etnologia-dos-povos-africanos-ndau1656).

Martinez L. (1989) O povo macua e sua cultura, Moç. Press, Maputo Medeiros, E. (1997) A cultura Macua em http://culturamocambicana.blogspot.com/2017/07/etnia-macua.

Meque, C.(2018) Globalização e sua influência nos elementos da cultura ndau, análise do caso da dança Xiquema em https://wwwresearchgate.net/publication/323638750, aos 29/04/2020.

Mercier, P. « Remarques sur la signification du "tribalisme actuel" en Afrique noire», Cahiers internationaux de sociologie, (Paris, PUF), XXI, JulhoDezembro, 1961, p. 65.

Moscovic, S. (1978) A Repesentação Social da Psicanálise, Rio de Janeiro. Zahar Moscovic, S. (1984). The Phenomenon of Social Representations. Em R. Farr \& S. Moscovici (org.), Social Representations. Cambridge: University Press.

Ngunga, A.; Faquir A, O. (2011) Padronização da ortografia de línguas moçambicanas: relatório do $3^{\circ}$ seminário. Maputo: CEA/UEM, 2011.

Patrício,M.(2011) Identidade Étnica, Regional ou Transnacional? O caso Ndau, XI congreso Luso-Africano UFBA, Bahia.

Santiago, E. (2012) A Cultura Moçambicana. Em: https://www.infoescola.com/cultura/cultura-mocambicana/.

Spink, M. J. P.(1993) The Concept of Social Representations in Social Psychology. Cad. Saúde Públ., Rio de Janeiro, 9 (3): 300-308, jul/sep. 
Tibane, A. (2014) A Análise Sóciodiscursiva da "Saudação" do Grupo Étnico Linguístico Tsonga em Moçambique em https://wwwresearchgate.net/publication/305680975.

Vala, J. (1996). Representações sociais: para uma psicologia social do pensamento social. In. Vala \& M. B. Monteiro (Eds.), Psicologia social. $2^{\mathrm{a}}$ ed (pp. 353-384).Lisboa: Calouste Gulbenkian.

Vigotsky, L. S., 1978. Mind in Society. Cambridge: Harvard University Press. https://www.colegiomoz.blogspot.com/2018/12/dancas-tradicionais-da-zona-

sul-de.html.

RESUMO:

O presente artigo, visa trazer uma reflexão sobre a teoria das Representações Sociais na óptica da Psicologia Social. A partir da revisão bibliográfica, faz-se uma analogia das teorias das representações sociais, a uma sociedade concreta, neste caso, a sociedade Moçambicana. As representações sociais, tem sido um tema amplamente discutido por vários e categorizados autores, muitos deles abordando a relação cogniçãoconhecimento, indivíduo e sociedade. Para o efeito, foram analisadas três etnias moçambicanas, nomeadamente, MacuasLomués, Ndaus e Tsongas, nas quais, a partir da constatação bibliográfica das sua culturas, crenças e valores, pode se fazer uma analogia real entre as teorias sobre as representaçãoes sociais e os comportamentos destas etnias, que deixam claras as diferentes representações socias nas diferentes regiões que formam o país chamado Moçambique. A base da pesquisa foi a revisão bibliográfica, tanto para abordar os suportes teóricos, assim como para abordar a realidade Moçambicana.

PALAVRAS-CHAVE: Represntações; Etnias; Macuas; Tsongas.

\section{RESUMEN:}

Este artículo tiene como objetivo traer una reflexión sobre la teoría de las Representaciones Sociales desde la perspectiva de la Psicología Social. A partir de la revisión bibliográfica, se hace una analogía entre las teorías de las representaciones sociales, a una sociedad concreta, en este caso, la sociedad mozambiqueña. Las representaciones sociales han sido un tema ampliamente discutido por varios y categorizados autores, muchos de ellos abordando la relación entre cognición-conocimiento, individuo y sociedad. Para ello, se analizaron tres etnias mozambiqueñas, a saber, Macuas-Lomués, Ndaus y Tsongas, en las que, a partir de la verificación bibliográfica de sus culturas, creencias y valores, se puede establecer una analogía real entre las teorías sobre las representaciones sociales y culturales. los comportamientos de estas etnias, que dejan en claro las diferentes representaciones sociales en las distintas regiones que conforman el país llamado Mozambique. La base de la investigación fue la revisión bibliográfica, tanto para abordar los soportes teóricos, como para abordar la realidad mozambiqueña.

PALABRAS-CLAVES: Representaciones; Etnias; Macuas; Tsongas. 